\title{
SUBJECT AREA TEACHERS' PROFESSIONAL COMPETENCE DEVELOPMENT NEEDS DURING THE TRANSITION TO TEACHING IN A SECOND LANGUAGE
}

\author{
Katri Raik, Igor Kostyukevich, Jelena Rootamm-Valter \\ Narva College of Tartu University, Narva, Estonia \\ E-mail: Katri.Raik@ut.ee, Igor.Kostjukevits@ut.ee, Jelena.Rootamm-Valter@ut.ee
}

\begin{abstract}
A partial transfer into teaching in the Estonian language is being implemented in Russian-medium upper secondary schools in Estonia. Among teachers who have to switch to teaching in Estonian are also subject who have previously taught in the Russian language. A number of surveys have shown that there are teachers who believe that methodological support of the transfer is not sufficient. Hence, it is important to find out if there is a need for additional in-service teacher training during the transfer period, and if yes, then what kind of training is required.

A model of subject teachers' professional competences was devised. The need analysis was conducted by the structural survey method among focus groups of subject teachers. Six Estonian Russian upper secondary schools were selected for the study on the basis of the representativeness of the criteria set to focus groups. The representative groups were offered to evaluate by rating professional competences, needs for additional in-service training, and, finally, needs for language support. The data were analyzed by the Pearson's correlation and by the analysis of the variations range of the three measured criteria at the level of separate schools and their teacher teams and at the level of indicators' mean values.

The research has not revealed any common data in either strong or weak points of teachers 'professional competences. Each school has a professional profile of its own. The need for in-service professional training depends on the professional profile of each school (correlation $0.835 \div 0.908$ ). The need for language support is also highly correlated with the conscious need for training.

Recommendations. Planning of partial transfer to teaching in the Estonian language, as well as an additional in-service training and language support should be based on the needs of a particular school. The system of in-service teacher training should take into consideration all components of teachers', professional competences while offering additional in-service training and language support on a regular basis. While implementing partial transfer of Russian-medium schools into teaching in the Estonian language it is absolutely necessary to apply an individual approach to each and every school.

Key words: competence development needs, teachers' professional competence, transition to teaching in a second language.
\end{abstract}

\section{Introduction}

Within the framework of the Eduko programme the Ministry of Education and Research of Estonia has requested Narva College of the University of Tartu to do meta-research with the aim to summarise and interpret research data available at the beginning of 2012 on the transition of Russian-medium schools to partial Estonian-medium instruction. The following tasks were defined for the meta-research:

1) To summarise the results of the studies conducted by various research groups into 
Katri RAIK, Igor KOSTYUKEVICH, Jelena ROOTAMM-VALTER. Subject Area Teachers' Professional Competence Development Needs during the Transition to Teaching in a Second Language

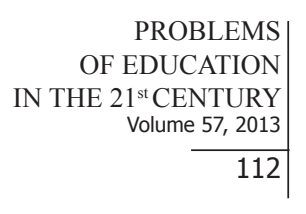

2)

different aspects of the transition period from 2006 till 2012;

2) To list recommendations made by the researchers to support teachers during the transition period: training, consulting, networking, etc., and to consider the outcomes of their implementation within the framework of a number of national educational programmes realized during that period;

3) On the basis of the received results to analyse possible reasons of transition period difficulties, and to understand why surveys reveal unsatisfactory assessment of the transition process.

The article is aimed to present research outcomes which refer to pedagogical qualifications of teachers who are performing the transition.

\section{Political and Legal Pre-requisites for the Transition of Russian-Medium Schools to Partial Estonian- Medium Instruction}

The transition of Russian-medium upper secondary schools to Estonian language instruction was effected in accordance with the Education Act adopted in 1992 after Estonia regained its independence (The Republic of Estonia Education Act $\S 4$ part 2). The Act created a basis for the Estonian school education reform which was aimed at the devising of new National Curricula for basic and upper secondary schools to follow key principles of freedom and democracy, to meet the requirements of European standards. As far as the language of school instruction is concerned, a national minority educational institution has the right to choose a language of instruction in accordance with the Constitution of the Republic of Estonia (The Constitution §37) on terms stipulated by corresponding Acts, i.e. by the National Curricula.

National Curriculum changes had been introduced by 2010 , after 18 years, by adopting a number of acts for basic schools and upper secondary schools (The Basic Schools and Upper Secondary Schools Act, 2010; The National Curriculum for Basic School, 2011; The National Curriculum for Upper Secondary School, 2011). The same acts regulate the process of the transition of national minority schools to partial Estonian language instruction. In accordance with these acts a second language medium basic school has instruction in a second language in the volume of at least $60 \%$ of its subjects, with the instruction to Estonian or any third or fourth language of $40 \%$. At the upper secondary school level, where education in a second language of a national minority is not guaranteed by the Constitution, subject instruction is presupposed to be in the Estonian language in the volume of at least $60 \%$ of subjects, whereby Estonian Literature, History of Estonia, Civic Studies, Music and Geography are to be taught only in Estonian.

Therefore, Russian-medium schools and other second language medium schools (Ukrainian, Armenian, Hebrew) found themselves in a situation when within a short period of time they had to perform principal changes in two areas: the restructuring of the curricula and the transition of the upper secondary school to partial Estonian-medium studies (60\% or more). A number of schools began to implement the transition to partial Estonian-medium instruction at the level of basic schools (not more than $40 \%$ ).

\section{The Process of Transition of Russian-Medium Schools to Partial Estonian Language Instruction}

The language of instruction is regulated by the Law which stipulates conditions for enjoying the constitutional right of receiving basic education in the Russian language (basic education in Estonia is provided by 9-year basic schools); and it also defines the principles which are to be followed in the transition of Russian-medium upper secondary schools to Estonian language instruction. The transition was planned to be completed by the year 2000. It was believed that there would be created a solid basis for school leavers to acquire a sufficient Estonian language mastery for their follow-up university studies as Russian-medium upper secondary schools were supposed to provide them with such opportunities. 
The Government performed a number of actions to prepare the transition process. Among these actions there were Estonian language study programmes for teachers and the preparation of necessary methodological support materials. In view of practical outcomes it could be stated that the governmental authorities were unreasonably optimistic in 1992. The transition of a big number of schools to students' second language instruction within a short period of time failed due to objective reasons. The restructuring of the whole system of education after Estonia had regained its independence required great efforts from both teachers and school administration staff.

In spite of the fact that many Russian-medium schools began to teach several subjects in the Estonian language, and they gradually increased their number during the coming years, their school leavers were not prepared for Estonian-medium tertiary education. That is why in 1997 a new plan for the transition was adopted; that time it was related to the introduction of new National Curricula, with separate requirements set to the transition of the upper secondary school. In accordance with the plan starting from 2007 teaching of one subject in Estonian - Estonian Literature - was mandatory, with one more core subject to be added every year. Thus, starting from 2011 all students of Russian-medium upper secondary schools was supposed to have $60 \%$ of studies in the Estonian language. It was also planned to adopt new National Curricula for Basic School and Upper Secondary School in the same 2011 year. (Haridusteave, 2011).

The transition of Russian-medium schools to partial Estonian language instruction had as one of its specific features the fact that subject teaching in Estonian was supposed to be conducted by teachers who used to teach in the Russian language. It was assumed that teachers' Estonian language mastery should have corresponded to the highest level (at present, to follow the EU Framework of Reference for Languages, it is C1). The knowledge of the language at this level is provided by receiving secondary, upper-secondary education or, mandatory for teachers, tertiary teacher education in the Estonian language. Since 1992 courses of the Estonian language have been offered specially for teachers who do not have the required mastery of the Estonian language.

During the whole period of the preparatory time other supportive activities and in-service teacher trainings were organized for teachers and teachers of upper secondary schools, in particular, to prepare the double transition: consulting-didactic centers widened the scope of their services; methodological support materials were published regularly, incl. on the topic of CLIL; corresponding in-service teacher training courses were offered regularly.

The on-going monitoring process supported the transition in the form of surveys and researches which analyzed performed activities and suggested necessary corrective actions. However, despite all the efforts and actions taken to prepare the transition to partial Estonian language instruction, some upper secondary schools had failed to reach the required standards by the beginning of the academic year of 2011/2012. In those circumstances the need for a detailed analysis and interpretation of the existing researches and surveys was of the utmost topicality. It is also important for the perspective planning of necessary effective measures to finish the transition in the interests of both students and teachers.

The following outcomes of surveys and researches into the transition of Russian-medium schools to partial Estonian language instruction, which were conducted in 2006-2011, have been used by the authors in their study of Russian-medium school subject-area teachers' needs in in-service teacher training. 
Katri RAIK, Igor KOSTYUKEVICH, Jelena ROOTAMM-VALTER. Subject Area Teachers' Professional Competence Development Needs during the Transition to Teaching in a Second Language

EMS

OF EDUCATION

IN THE $21^{\text {st }}$ CENTURY

Volume 57, 2013

114

\section{Subject-area Teachers'Professional Competence in the Context of the Transition of Russian-Medium Schools to Partial Estonian Language Instruction}

To reason the choice of the topic of the authors' research, an overview of the metaresearch is presented below to highlight its topicality. A separate section of the references at the end of the article gives a full list of the researches the outcomes of which have been summarised.

The most important aspect revealed in the process of the analysis is the fact that none of the conducted surveys and researches has studied the process of Russian language instruction in Russian-medium schools. The only aspect which is mentioned is the results of PISA tests which are lower in Russian-medium schools in comparison with Estonian-medium schools. However, there is an obvious tendency towards their improvement and reaching the levels of Estonian-medium schools' results. Basing on this criterion, it can be assumed that the transition of Russian-medium schools to partial Estonian language instruction is connected with the improvement of academic results. It can be suggested that this improvement has been caused by an intensive methodological support of the transition process.

Considering factors which can influence the transition to Estonian language instruction the researches under analysis allow the authors to classify them into three groups: attitudes, managerial and professional factors.

Attitudes comprise, for example, differences in school administration's and teachers' perceptions of assessment criteria set to pedagogical activities. Multiculturalism ${ }^{1}$ being a necessary pre-requisite and environmental factor of modern education is not highly supported by school management; at the same time school teachers believe it to be of great importance. With this attitude, it can be assumed that managerial support from school administrations is not enough. It is worth mentioning that administration staff and school teachers in their majority have an opinion that managerial questions are to be solved outside the school: by the Ministry, universities, students' families, etc.

The lack of appreciation of teachers' work to a certain extent can be also viewed as a managerial factor. In its turn it influences work motivation ${ }^{2}$, as well as development ${ }^{3}$. This factor should be considered as an external to the educational process factor on which its participants have but a limited impact. The factor is common for teachers of both Russian and Estonian-medium schools.

Finally, in view of the professional aspect it has been revealed that there is a wide usage of ineffective teaching methods: teachers' and students' efforts do not produce expected learning outcomes, which is shown with the PISA test results, for example, and some other quality education indicators. This situation is characteristic of school teachers of both Estonian and non-Estonian-medium schools. As this aspect is tightly connected with the education process its participants - teachers - can directly influence on it. If the conditions are favorable, this is exactly what happens.

During the transition to second language instruction the provision of methodological and didactical support organized and coordinated by the Ministry of Education and Research creates such favorable conditions. The lack of appreciation of teachers' work and the absence of the common understanding of the concept of multilingualism are believed to be negative aspects. The range of aspects characteristic of the transition period is much wider, but it is out of the scope of the topic of the present analysis.

$1 \quad$ Multiculturalism is understood as coexistence of different traditions, concepts, beliefs, and other values and attitudes which have system differences shaped by languages and historical backgrounds.

2 Motivation is understood as a set of factors that originate both within as well as beyond an individual's being, to initiate work-related behavior, and to determine its form, direction, intensity, and duration (according to Latham and Pinder, 2005).

3 On the importance of recognition in the process of lifelong learning see (Wlodkowski, 1991). 
Katri RAIK, Igor KOSTYUKEVICH, Jelena ROOTAMM-VALTER. Subject Area Teachers' Professional Competence Development Needs during the Transition to Teaching in a Second Language

\section{Methodology of Research}

\section{Focus Research of Russian-Medium School Subject-area Teachers' Needs at the Transition to Estonian Language Instruction}

The key issue of the research lies in the fact that a number of surveys conducted among Russian- medium school teachers at different times show that the teachers consider the methodological support provided for the transition to be insufficient. As the surveys suggest the need for effective methodological support has not been satisfied yet on a regular qualitative basis. The teachers mention the insufficient number of in-service training courses and their shortness in time as well as their too general subject matters. This cannot but surprise considering the fact that since 1997 these aspects of in-service training have been paid the utmost attention and effort to. The teachers express the opinion that regional differences are to be taken more seriously into consideration while planning in-service training. However, the researches have not revealed any specific regional differences in the transition process. With this discrepancy in the previous researches, it seems to be reasonable to conduct an additional detailed study into teachers' professional competences and their needs in in-service teacher training. The outcomes of the proposed research are aimed at providing a targeted and affective support to teachers during the transition process to second language instruction. The aim of the focus research was to reveal drawbacks of in-service teacher training offered to subject-area.

The aim of the focus research was to reveal drawbacks of in-service teacher training offered to teachers, to define real needs in additional training - in in-service teacher training as well as in language support and scaffolding.

It was assumed at the beginning of the research that the teacher possesses all necessary competences needed for subject teaching in the language of instruction. In the focus of the authors' attention there were professional-pedagogical competences of subject-area teachers.

The following main hypotheses and research tasks were formulated:

1) A number of difficulties of the transition to subject teaching in a second for a teacher language - the Estonian language - are caused by the lack of professionalism. The research task was to define these problematic areas. To perform this analysis it was necessary to assess the elements of the professional competence of teachers.

2) Teaching in a second language sets different requirements to professional competences of teachers.

3) Teachers' conscious need in in-service teacher training does not meet real needs. The research task was to define this need by evaluating needs in in-service teacher training as such and the need in Estonian language support.

4) There are regional differences in teachers' professional qualities. It was necessary to determine in what way these professional qualities differ.

\section{The Model of Subject-Area Teachers' Professional Competences}

To devise the model it was assumed that the teacher possesses all necessary competences needed for subject teaching in the language of instruction. In the focus of the authors' attention were professional-pedagogical competences of subject-area teachers.

The model of subject-area teachers' professional competences was devised on the basis of existing occupational qualification standards for teachers (Õpetaja 7-1, 2013; Õpetaja, 7-2 2013), and in accordance with the requirements of the Master's Curriculum of Narva College of the University of Tartu "Teacher of Humanities in Multilingual School" (Humanitaarainete õpetaja mitmekeelses koolis, 2013). This particular Master's curriculum was chosen for the analysis because it is the only one in Estonia which provides teacher education for Russianmedium schools in the transition process to partial Estonian language instruction.

Professional competences are divided into two groups. Firstly, they are didactic compe- 
Katri RAIK, Igor KOSTYUKEVICH, Jelena ROOTAMM-VALTER. Subject Area Teachers' Professional Competence Development Needs during the Transition to Teaching in a Second Language

OF EDUC

PROBLEMS

IN THE $21^{\text {st }}$ CENTURY Volume 57, 2013

116 tences and skills which are aimed at subject acquisition. The second group consists of managerial competences and skills which support subject acquisition by the use of appropriate methodological and didactic principles, techniques in class planning. The list of the methodological and didactic competences and skills which was offered to focus groups for the assessment of their competences is as follows:

Didactic skills to ensure subject acquisition: setting of class aim/aims; devising of class plans (incl. the use of methodological and research literature, search for relevant examples for in-class work, creating of activities); creating of visual aids; the use of active teaching methods in the class; class organisation for having all activities in the right tempo and speed; checking and assessment of home assignments; the student-centered teaching approach.

Class management skills to ensure transitions between lesson stages: to conduct a warmup introductory part of the lesson; oral evaluation and assessment of knowledge in the class; explanation of difficult material (the "I have not understood" situation solution); revision and consolidation of the learned material; presentation of a new topic; organisation of student's independent work in the class; discipline and order management in the class; summing up of the lesson outcomes, conclusions.

\section{Instruments and Procedures}

To process the outcomes of the conducted social researches the method of focus group interviews was applied (Krueger 2002).

Basing on the research tasks, groups were supposed to represent various in their population composition counties of the country:

1) with the dominating proportion of Russian speaking population - Ida-Viru County (Narva and the county), taking the second place among the counties in terms of the number of its population;

2) with approximately of one half of Russian speaking population - Harju County (mostly Tallinn), where the number of Russian speaking people is comparatively higher, and LääneViru County;

3) with the dominating Estonian speaking population and a comparatively small number of Russian speaking people - all other counties of Estonia.

At the first stage of the research interviews were conducted among two focus groups of subject-area teachers of Russian-medium schools in Narva; the group consisted of teachers of humanities from seven schools. The interview outcomes did not reveal any common features in the answers of the respondents. This result caused doubts about the research hypothesis about regional differences and about the principle of forming focus groups of teachers from different schools of one region. Hence, the decision was taken to form focus groups on the principles of inviting teachers from one school of one region, and of making such groups in different schools.

As a result, depending on the proportion of Russian speaking population in various regions, two focus groups presented Narva, one group presented Ida-Viru County (Ahtme upper secondary school in Kohtla-Järve, two groups - Tallinn (secondary school 53 and Russian upper secondary school Lasnamäe), and one group - Tartu (Annelinna upper secondary school) which represented the third type of Estonian counties. None of the above schools belong either to the weakest or the strongest schools in Estonia as per the national examination results. In 2012 there were 230 upper secondary schools in Estonia; while deciding on the choice of respondents the first and the last 10 schools were excluded (Eesti koolide pingerida 2013).

Focus interviews were carried out in six groups of six teachers each. The informants teach Arts and Sciences. Subject-area teachers work in Russian-medium schools and teach in both Estonian and Russian, or they used to teach in Russian and then they switched to Estonian as the language of instruction. The representative groups were offered to evaluate by rating, first 
of all, the degree of Russian-medium school teachers' professional competences in subject-area teaching from the highest to the lowest. Then, similarly, the respondents were asked to evaluate

PROBLEMS

OF EDUCATION

IN THE $21^{\text {st }}$ CENTURY

Volume 57,2013 the degree of Estonian language acquisition, and, finally their preferences for in-service training. The above presented list of competences and skills was used as the criteria for assessment. The interview was recorded in writing; the identity of the rating terms was provided.

The following tasks were offered: 1) Imagine a situation when you teach your subject in Russian in the way you are used to. Please rate the given list of skills you possess by starting from the ones you master better than others. 2) Imagine that you are offered to improve one of the skills from the list at your choice, without any pre-requisites and limitations, on condition that all of the skills are to be developed and improved. In what order would you place them? 3) Imagine yourself being in a situation when you teach a subject in Estonian. Which of the listed skills will require more support with the Estonian language? Please rate the given list of skills by starting with the ones where you need this kind of support the most. Didactic competences and skills needed for class planning and transition from one lesson stage to the other were offered for rating in one set.

\section{Data Analysis}

The focus group research data present ratings of the importance of the criteria under analysis. To process the data standard non-parametric statistic methods were applied. Spearman's rank correlation coefficients were used to establish relations between the criteria, with Kendall's coefficient of concordance being applied to define the degree of opinion consistency of various focus groups. The follow-up calculations were performed with the application of IBM SPSS Statistics, the illustrative material was presented with the help of Microsoft Excel (Bühl and Tsefel, 2005, Nasledov, 2011, Elliott, 2007).

\section{Research Results}

The research into subject-area teachers' professional competences and skills has not revealed any common for all schools, groups or regions strong or weak points in the area of teachers' professional skills and competences (Figure 1). The research has not shown any common preferences among teachers of all six focus groups. The resulted coefficients of concordance were statistically insignificant. The graphs below clearly demonstrate it.

Therefore, the outcomes, reported in records where explanations of the group members were recorded, show that there is its individual professional profile in each and every school. These profiles reveal competences and skills which require further development, thus, the objective needs in in-service teacher training can be defined for each school.

The next stage of the analysis was aimed at establishing correspondence between real needs in in-service teacher training and teachers'conscious needs in additional training. The results of two schools (Figures 2 and 3 ) are shown below; the type of data for other schools is similar. 
Katri RAIK, Igor KOSTYUKEVICH, Jelena ROOTAMM-VALTER. Subject Area Teachers' Professional Competence Development Needs during the Transition to Teaching in a Second Language

PROBLEMS

OF EDUCATION

IN THE $21^{\text {st }}$ CENTURY

Volume 57,2013
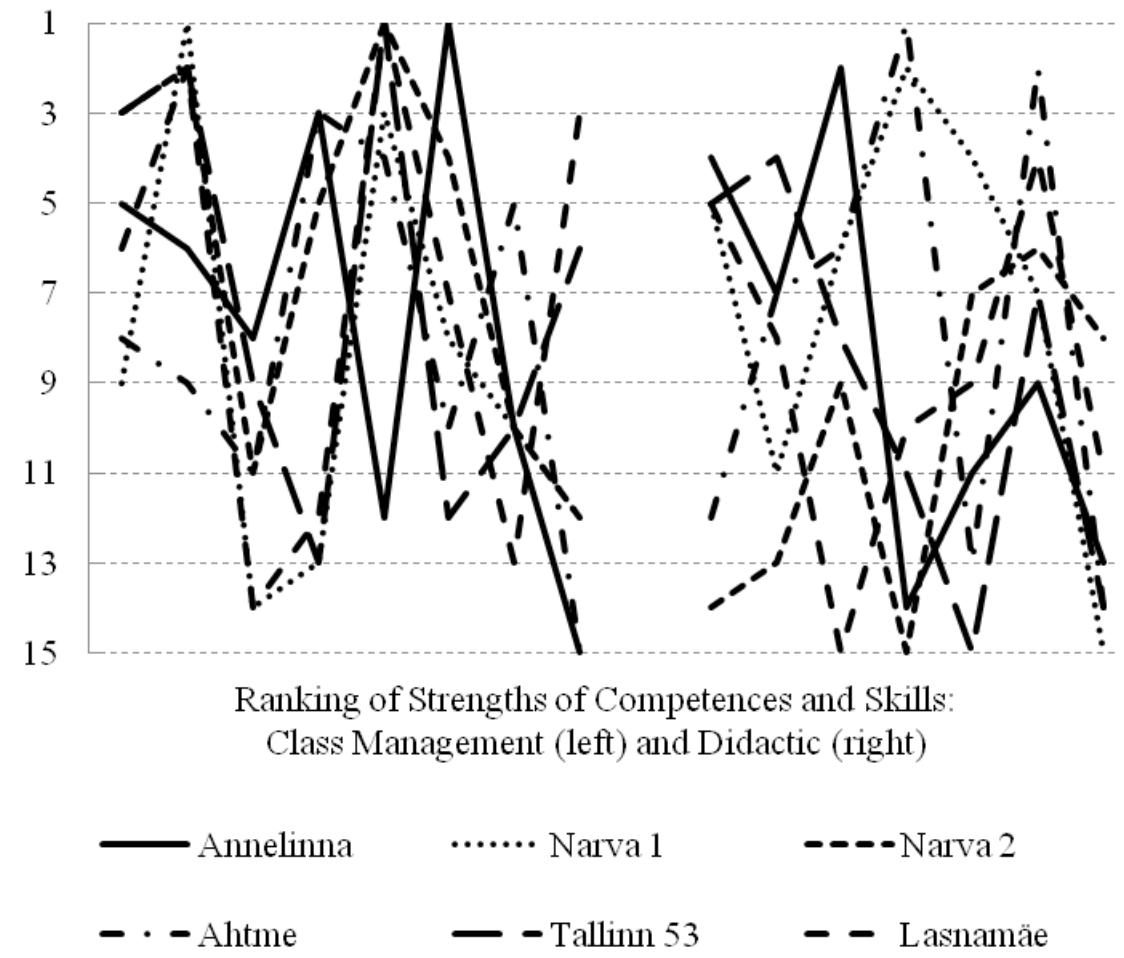

Figure 1: Assessment of Subject-area Teachers' Professional Competences and Skills.

Ahtme

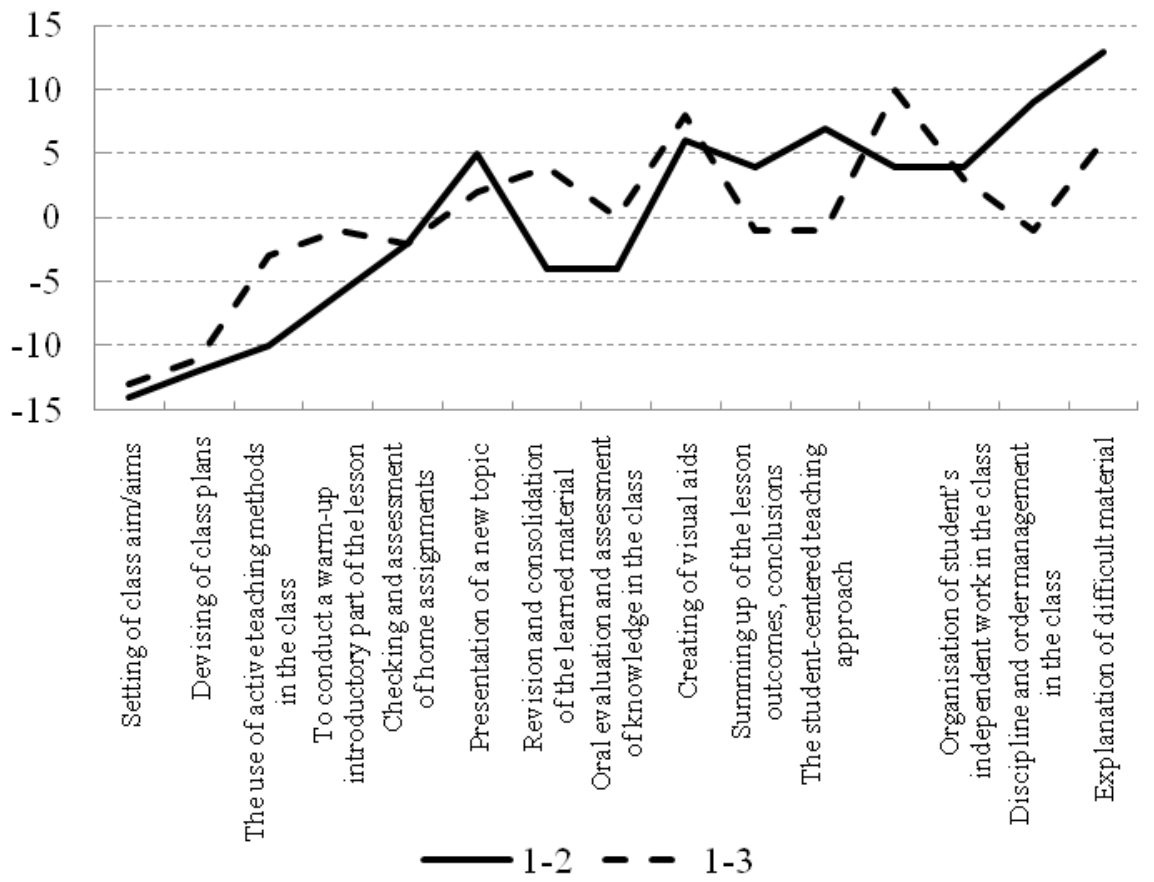

Figure 2: Teachers' Conscious Needs in In-service Teacher Training and Language Support (1). 
Katri RAIK, Igor KOSTYUKEVICH, Jelena ROOTAMM-VALTER. Subject Area Teachers' Professional Competence Development Needs during the Transition to Teaching in a Second Language

PROBLEMS

OF EDUCATION

IN THE $21^{\text {st }}$ CENTURY

Volume 57,2013

Annelinna

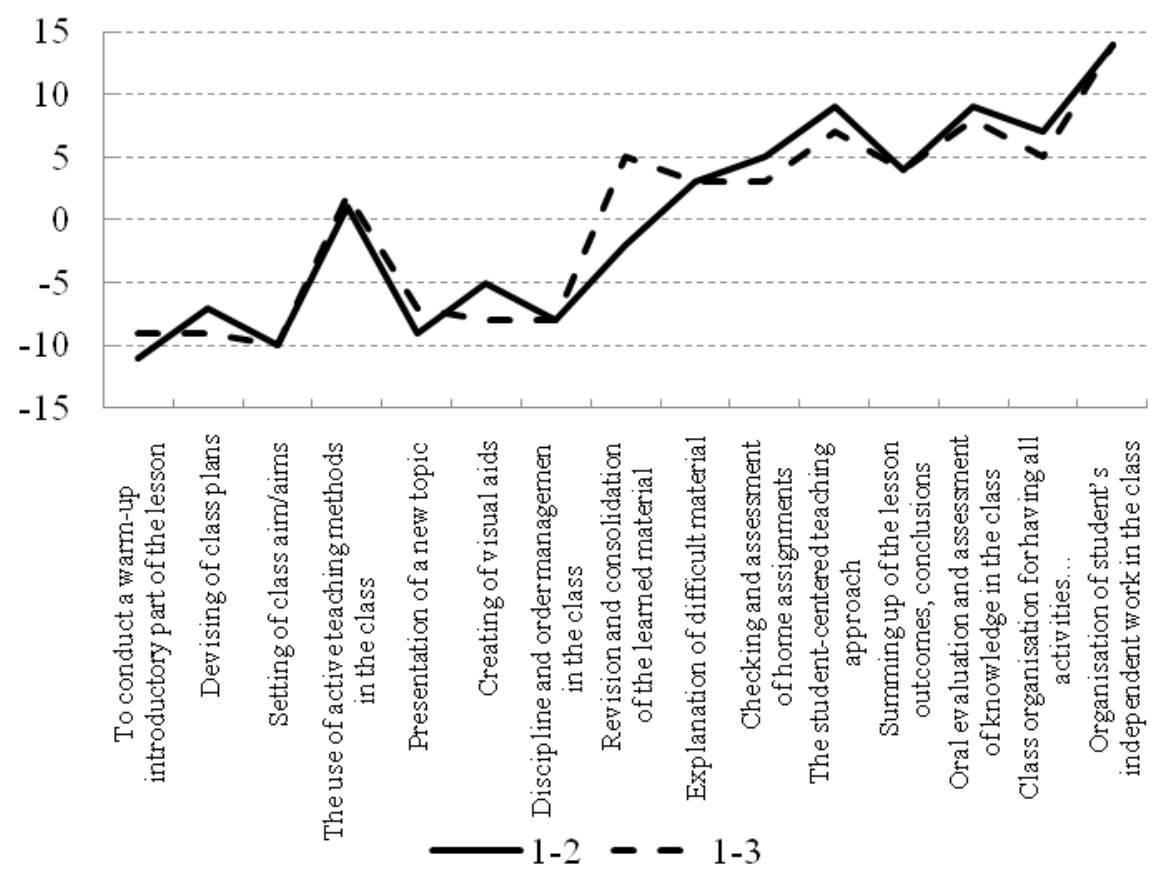

Figure 3: Teachers' Conscious Needs in In-service Teacher Training and Language Support (2).

The research has revealed the correspondence between teachers' conscious needs in inservice training and the ratings used for the assessment of the professional competences and skills. The graphs present rating differences between "Subject-area Teachers' Strength" and "What Needs to Be Studied" (marked as 1-2); and between "Subject-area Teachers' Strengths" and "What Needs to Be Studied for Conducting Classes in the Estonian Language" (marked as 1-3) against the rating of "Subject-area Teachers' Strengths" (located on the horizontal axis starting from the highest by its rating/importance one) .

The graphs demonstrate the following systemic correlation: the lower certain skills are evaluated the higher the need in in-service training or language support is required.

This type of correlation (1-2) is characteristic of all focus groups. Corresponding Spearman's rank correlation coefficients fluctuate within the range of $0.75-0.90$, with the significance level being $\mathrm{p}<0.01$.

Figure 4 below summarises teachers' conscious needs in in-service training. 
Katri RAIK, Igor KOSTYUKEVICH, Jelena ROOTAMM-VALTER. Subject Area Teachers' Professional Competence Development Needs during the Transition to Teaching in a Second Language

OF EDUCATION

IN THE $21^{\text {st }}$ CENTURY

Volume 57, 2013

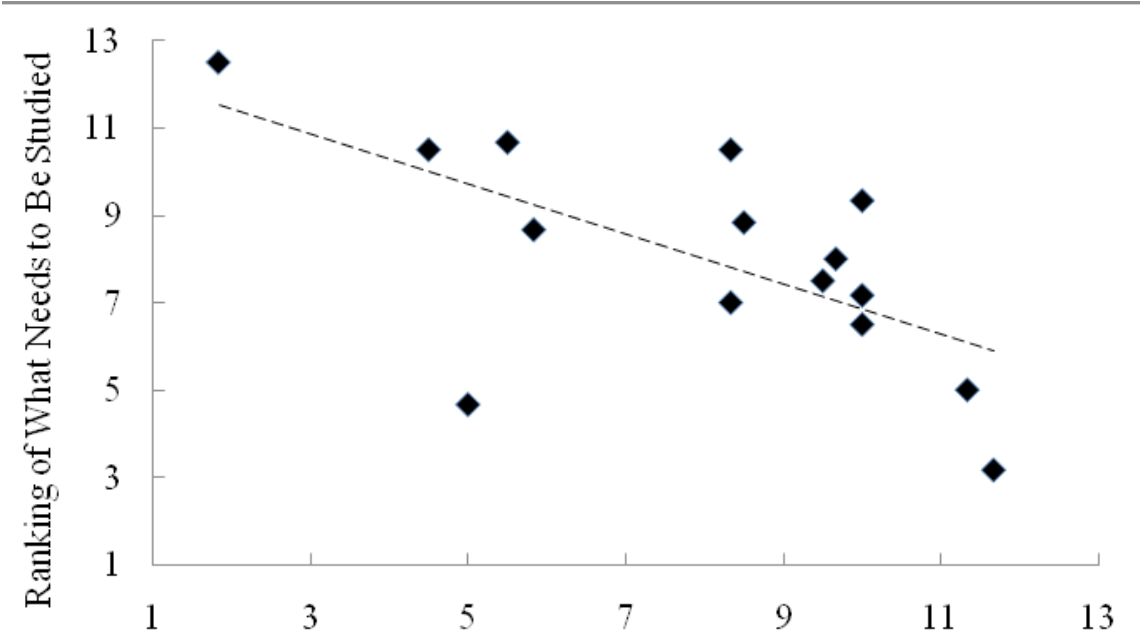

Ranking of Strengths of Competences and Skills

\section{Figure 4: All Group Teachers' Conscious Needs in In-Service Training in View of Strength of Professional Competences and Skills.}

The research has revealed the correlation between teachers' conscious needs in in-service teacher training and the evaluations of the elements of the professional competences and skills. The range of fluctuation of Spearman's rank correlation coefficient for six groups was 0.81-0.91. Therefore, it can be concluded that teachers do realise that they need additional training to master professional skills which require further development. The records' evidence clearly shows that in spite of active discussions of opportunities to improve skills they master better than others, teachers give priorities to further development of the weakest skills. To explain their choice teachers did not refer to the rating itself by saying "let us look at what we decided when we rated skills": the choice is explained by giving substantial reasons.

Figures 3 and 4 also present needs in language support, i.e. in improving Estonian language mastery as the language of instruction. With the language support factor there is a correlation similar to the one observed in the case of the degree of professional skills mastery and conscious needs in additional in-service teacher training. Spearman's rank correlation coefficients of five focus groups fluctuate within the range from $0.60(p<0.05)$ to $0.90(p<0.01)$. With one of the groups the correlation is close to a statistically significant value $(0.49, \mathrm{p}=0.063)$.

Rank averaging of all focus groups has resulted in the 'smearing' of the listed above particularities. To illustrate, the following summary figure presents the averaged data of the parameters "What Needs to Be Studied" and "What Needs to Be Studied for Conducting Classes in the Estonian language" (Figure 5). 


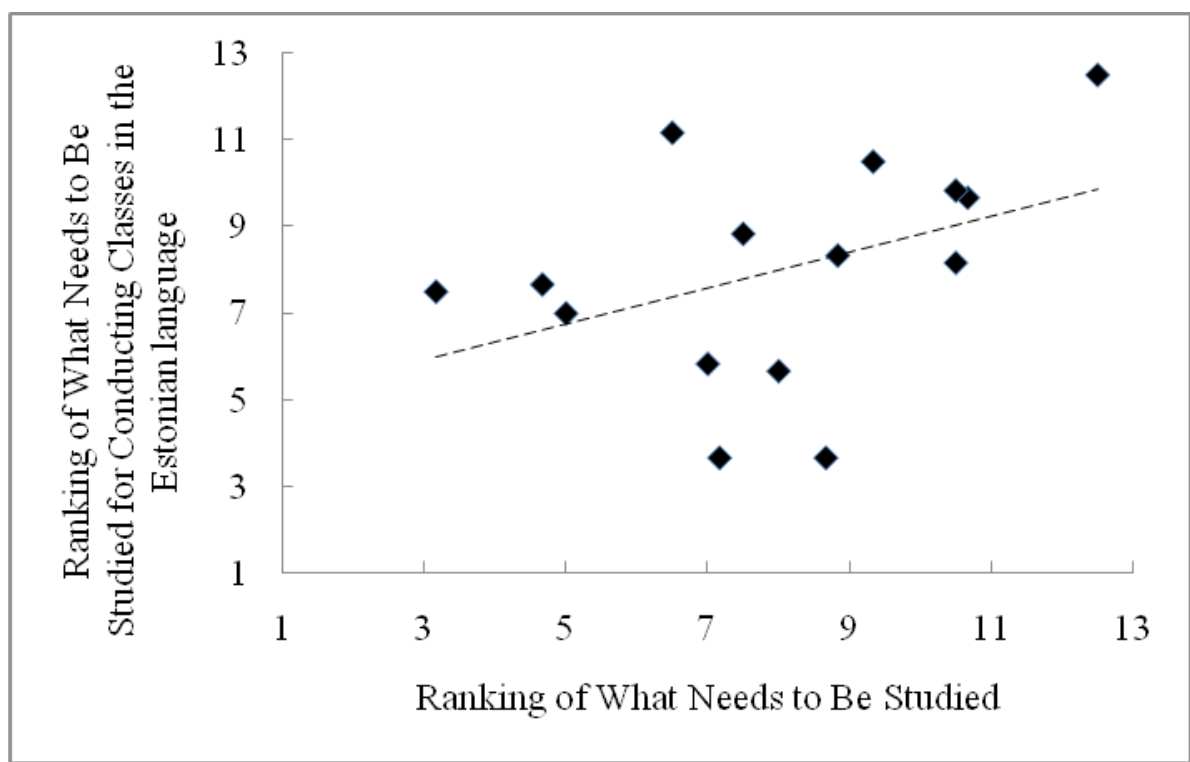

\section{Figure 5: All Group Teachers' Needs in Language Support in View of Teachers' Conscious Needs in In-Service Training.}

For this couple of variables Spearman's rank correlation coefficient equals $0.46(\mathrm{p}=0.08)$, i.e. it is close to a statistically significant value, which allows to assume that needs in additional in-service teacher training and in language support are interconnected. To conclude, teaching in a second language does not require from a teacher additional professional competences and skills in comparison with teaching in the native language, or mother tongue of the teacher. It is a wrong assumption that professionalism depends on the language of instruction mastery.

\section{Conclusions}

The transition of Russian-medium schools to partial Estonian language instruction has attracted more attention to teacher professionalism.

It has been revealed that weaknesses in teacher professionalism do not depend on the language of instruction; hence, these two characteristics should not be connected with each other. The outcomes of the previous researches, which stated that there were no particular regional differences of the transition of Russian-medium schools to partial Estonian language instruction, have been confirmed. The public opinion on this matter differs from what the actual situation is about.

By defining weak and strong points in the professional qualification of subject-area teachers at the level of competences and skills it can be stated objectively that there is a need in additional in-service teacher training. Each school has its own scope of such needs. The research has not presented any common for all Russian-medium schools weak points in the teachers' professional competence. Therefore, while offering in-service teacher training courses and other measures to support the development of teachers' professional competences; it is important to apply a multifaceted approach providing additional training of all components of the teachers' professional competence on a regular and systematic basis. The priority should be given to specific study programmes aimed at the development of a particular component of the teachers' professional competence instead of offering programmes of a wide area profile. The same conclusions can be made regarding language support. Language support courses should be offered together with in-service teacher training. 
Katri RAIK, Igor KOSTYUKEVICH, Jelena ROOTAMM-VALTER. Subject Area Teachers' Professional Competence Development Needs during the Transition to Teaching in a Second Language

OF EDUCA

IN THE $21^{\text {st }}$ CENTURY Volume 57,2013

Teachers' conscious needs in in-service teacher training do correspond to real needs. While planning in-service teacher training courses it is recommended to take into consideration the fact that teachers assess their needs in additional in-service teacher training in accordance with their perception of the professional competence they actually have. In view of these data it seems to be highly reasonable to compose a competence profile for each school, which will help to plan in-service teacher training for each school in particular, and it will allow focusing the efforts of the system of in-service teacher training on the real needs of teachers in a particular school.

It can be stated that the conducted focus group research has permitted to explain certain discrepancies in the results which were obtained from previous sociologic surveys and monitoring studies. The research has provided an opportunity to reconsider and develop the previous researches' outcomes and, on their basis, to formulate recommendations of how to solve topical problems of the transition of Russian-medium schools to Estonian language instruction in a much more efficient way.

\section{References}

Bühl, A., Tsefel, P. (2005). SPSS: искусство обработки информации [SPSS: The Art of Data Processing]. Moscow: DiaSoft.

Eesti koolide pingerida. (2013). Postimees. Retrieved 21/10/2013 from http://www.postimees.ee/export/ riigieksamid/2012.

Eesti inimarengu aruanne 2006-2011. (2007). Tallinn: Eesti Koostöö Kogu.

Eesti lõimumiskava eesmärkide saavutamise monitooring (2010). Tallinn: MEIS.

Eestikeelne aineõpe vene õppekeelega koolides: hetkeolukord ja vajadused (2006). Tallinn: MEIS.

Eestikeelne aineõpe vene õppekeelega koolide gümnaasiumiastmes: mitte-eestlaste teadlikkus ja suhtumine ning seda mõjutavad tegurid (2008). Tallinn: TNS EMOR.

Elliott, A. C. (2007) Statistical analysis quick reference guidebook: With SPSS examples. L.A.: Sage Publications, Inc.

Haridusteave (2012). Opetajate leht 16.12. 2011 No 46. Retrieved 3/11/2013 from http://opleht.ee/ arhiiv/?archive_mode $=$ article\&articleid $=6595$.

Henno, I. (2011). Eesti ja vene õppekeelega õpilaste sooritused PISA 2006-s ja 2009-s. Tallinn: HM.

Humanitaarainete õpetaja mitmekeelses koolis (2531). (2012). Narva: Tartu Ülkiooli

Narva Kolledž. Retrieved 18/10/2013 from https://www.is.ut.ee/pls/ois/!tere.tulemast?naita_ka alternatiive $=1 \&$ naita_ka_alternatiive $=1 \& l e h t=$ OK.BL.PU\&id_a_oppekava $=4071 \&$ kordi_ pealehel $=1 \&$ systeemi seaded $=3,1,12,1, \&$ viida $\% 20 \mathrm{kaudu}=1 \&$ sessioon $=0$.

Kello, K. (2009). Projekti „,Vene laps venekeelse üldhariduskooli eestikeelses õppes” raames 2008. aastal toimunud fookusgruppide analüüs. TÜ haridusuuringute ja õppekavaarenduse keskus.

Kello, K., Masso, A., Jakobson, V. (2011). Projekti „Vene laps venekeelse üldariduskooli eestikeelses oppes" lõpparuanne. Tartu: TÜ haridusuuringute ja õppekavaarenduse keskus.

Krueger, R. A. (2002). Designing and Conducting Focus Group Interviews. Minneapolis: University of Minnesota. Retrieved 18/09/2013 from http://www.eiu.edu/ ihec/Krueger-FocusGroupInterviews.pdf.

Latham, G. P., Pinder, C. C. (2005). Work Motivation Theory and Research at the Dawn of the Twenty First

Century. Annual Review of Psychology, 56, 485-516. Retrieved 17/11/2013 from www.researchgate.net/...motivation.../60b7d51714d8763d9c.pdff.

Loogma, K., Ruus, V. R., Talts, L., Poom-Valickis, K. (2009). Õpetaja professionaalsus ning tõhusama õpetamis- ja õppimiskeskkonna loomine. OECD rahvusvahelise õpetamise ja õppimise uuringu TALIS tulemused. Tallinn: TLÜ haridusuuringute keskus.

Masso, A., Kello, K., Jakobson, V. (2008). Uurimisprojekti "Vene laps venekeelse üldhariduskooli eestikeelses õppes” 2008. aasta tulemustest. Tartu: TÜ haridusuuringute ja õppekavaarenduse keskus.

Masso, A., Kello, K. (2010). Vene õppekeelega koolide valmisolek eestikeelsele gümnaasiumiõppele üleminekuks. Projekti ,Vene laps venekeelse üldhariduskooli eestikeelses õppes“ raames 2009. aastal õpetajate ja 11. klasside õpilaste hulgas läbiviidud standardiseeritud küsitluse analüüsi tulemused. Tartu: TÜ haridusuuringute ja õppekavaarenduse keskus. 
Katri RAIK, Igor KOSTYUKEVICH, Jelena ROOTAMM-VALTER. Subject Area Teachers' Professional Competence Development Needs during the Transition to Teaching in a Second Language

Mehisto, P. (2009) Hiliskeelekümblusprogrammi jätkusuutlikkus. Uuringu aruanne. Tallinn: HM.

Nasledov, A. (2011) SPSS 19: Профессиональный статистический анализ данных [Professional Statistic

Data Analysis]. St. Petersburg: Piter.

Noorte kodanikukultuur kümme aastat hiljem. (2009). Eesti tulemused IEA rahvusvahelises kodanikuhariduse uuringus ICCS 2009. Tallinn: TLÜ riigiteaduste instituut.

Projekt „Muukeelne laps Eesti koolis”. (2012). Lõpparuanne. Tallinn: TLÜ psühholoogia instituut.

Sau-Ek, K., Loogma, K., Võõbus, V. (2008). Keelekümbluse 2007-2008. aasta uurimuse aruanne (leping $n r$ 10-10/1714). Tallinn: TLÜ haridusuuringute keskus.

Sau-Ek, K., Loogma, K., Vainu, V. (2010). Keelekümbluse 2010. aasta uurimuse aruanne. Tallinn: TLÜ haridusuuringute keskus.

Ugur, K., Raudvassar, L.(2011). Ülevaade tugirühmade kasutamise kogemusest eestikeelsele aineõpetusele üleminevate õpetajate toetamisel. Tartu: TÜ haridusuuringute ja õppekavaarenduse keskus.

The Republic of Estonia Education Act. Adopted on 23.03.1992, RT 1992, 12, 192, § 4 part 2.

The Constitution. Adopted on 28.06.1992. RT 1992, 26, 349, § 37.

The Basic Schools and Upper Secondary Schools Act. Adopted on 09.06.2010. RT I 2010, 41, 240.

The National Curriculum for Basic School. Adopted on 06.01.2011, RT I, 14.01.2011, 1.

The National Curriculum for Upper Secondary School. Adopted on 06.01.2011, RT I, 14.01.2011, 2.

Wlodkowski, R. J. (1991). Developing Motivation For Lifelong Learning. The Learning Revolution. IC\#27 Winter 1991. Langley: Context Institute. Retrieved 17/11/2013 from http://www.context. org/iclib/ic27/wlodkski/.

Õpetaja 7-1, 21-15052013-2.1/4k Kutsekoda. Tallinn: Kutsekoda. Retrieved 18/10/2013 from http:// www.kutsekoda.ee/et/kutseregister/kutsestandardid/10467750.

Õpetaja 7-2 21-15052013-2.2/1k (2013) Kutsekoda. Tallinn: Kutsekoda. Retrieved 18/10/2013 from http://www.kutsekoda.ee/et/kutseregister/kutsestandardid/10467812.

Advised by Laima Railiene, University of Siauliai, Lithuania

Received: September 30, 2013

Accepted: December 16, 2013

PROBLEMS

OF EDUCATION

IN THE $21^{\text {st }}$ CENTURY

Volume 57, 2013

123 